\title{
Actinomycetoma caused by Nocardia brasiliensis
}

Actinomicetoma por Nocardia brasiliensis

\section{Roberta Leste Motta ${ }^{1}$, Raquel Virgínia Rocha Vilela ${ }^{2}$ and José Roberto Lambertucci ${ }^{2}$}

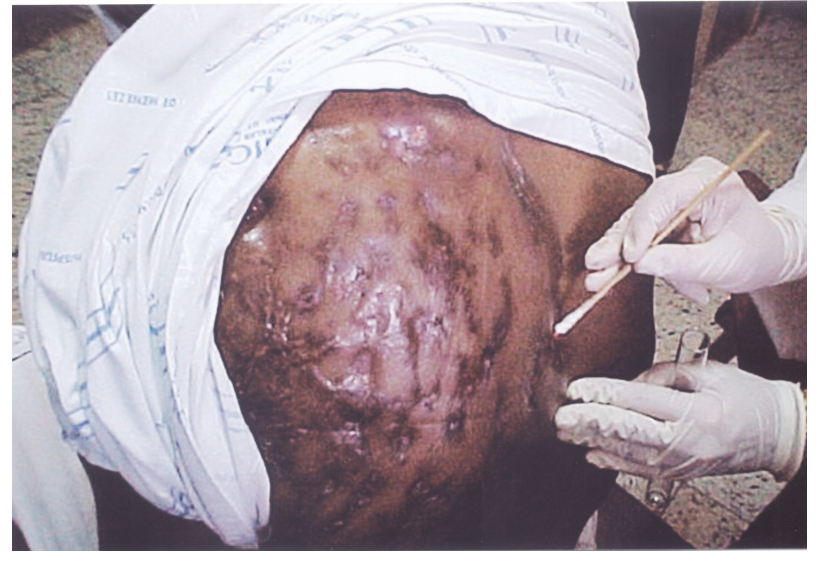

A

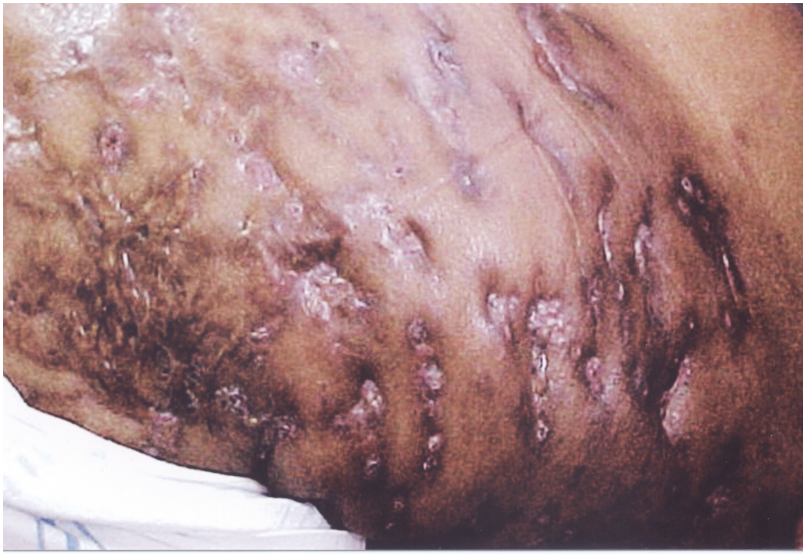

B

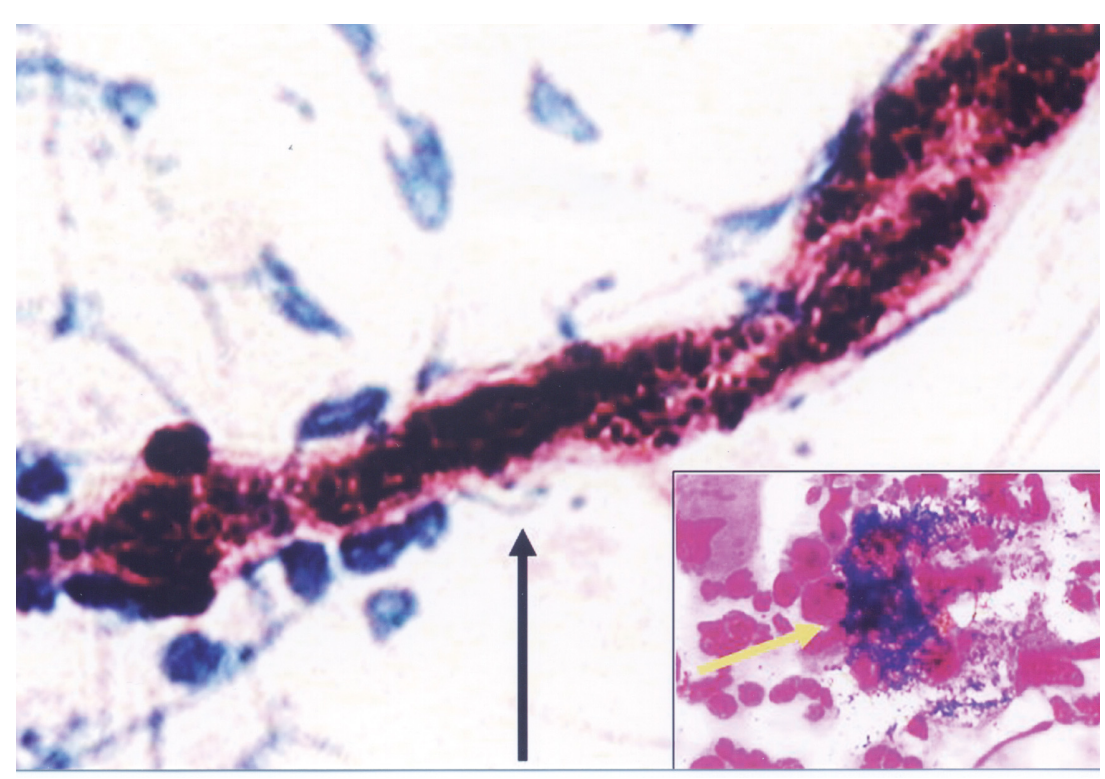

C

1. Serviço de Dermatologia do Hospital Eduardo de Menezes, FHEMIG, Belo Horizonte, MG. 2. Serviço de Doenças Infecciosas da Faculdade de Medicina da Universidade Federal de Minas Gerais, Belo Horizonte, MG

Address to: Prof. José Roberto Lambertucci. Faculdade de Medicina da UFMG. Avenida Alfredo Balena 190, 30130-100 Belo Horizonte, MG, Brazil.

e-mail: lamber@uai.com.br

Recebido para publicação em 26/3/2004

Aceito em $7 / 5 / 2004$ 
An otherwise healthy 74-year-old Brazilian man, employed as a rural worker in the sugar cane plantations, was referred to the hospital with a raised skin lesion on the left cervical area, left shoulder, and ipsilateral dorsal thoracic region. The disease started two years before admission with nodules which evolved with bright tumefactions, formation of multiple sinuses, fistulous tracts that communicated with each other and ulcerated areas of the skin. The progressive proliferation of granulation and scar tissue led to enlargement and disfigurement of the affected part ( Figures A and B). Sinus tracts drained whitish grain-filled pus. After the initial discomfort he noticed the spread of the skin lesion and an increase in local pain during the previous 6 months. The patient was treated with skin creams and intravenous antibiotics, withoutimprovement. The material draining from the fistulous tracts was collected ( Figure A) and the grains were separated for culture and directexamination for bacteria. A filamentous Gram positive coccus-like agent was observed after staining ( Figure C- yellow arrow). Amodified ZiehlNeelsen stain (Kinyoun stain) identified Nocardia sp (Figure C black arrow) . White-yellowish granular bacterial colonies grewin the culture medium used (Sabouraud's agar, blood agar and chocolate agar), thus confirming the diagnosis of Nocardia brasiliensis. The patient was treated with a combination of trimethoprim-sulfamethoxazole $(160 / 800 \mathrm{mg})$ twice daily for 12 months. There was complete recovery from the infection and disappearance of the corresponding symptoms, buta residual dark scar remained in the affected area.

0 paciente, de 74 anos de idade, trabalhador em região canavieira de Minas Gerais (Lajinha) , relatava a presença de lesões cutâneas elevadas em região cervical, ombro e dorso esquerdo de início, havia dois anos. Os nódulos evoluíram para lesões tumefeitas, de superfície brilhante, com fístulas múltiplas de desembocadura carnosa e lesões ulceradas que drenavam material sero-purulento e pequenos grãos brancacentos. A proliferação de tecido granuloso e a presença de cicatrizes provocaram tumoração e deformação da área afetada (Figuras A e B) . 0 desconforto inicial deu lugar à extensa lesão cutânea que evoluiu com dor forte nos últimos seis meses. Fez uso de cremes para a pele e antibióticos sistêmicos, sem melhora. Parte da secreção que drenava das fístulas foi coletada ( Figura A), separando-se os grãos para exame bacteriológico e cultura. Ao Gram, identificaramse filamentos cocóides Gram positivos ( Figura C - seta amarela). Ao Kinyoun havia filamentos álcool-ácido resistentes com características de Nocardia sp ( Figura C- seta preta). Nas culturas realizadas em ágar Sabouraud, ágar sangue e ágar chocolate cresceram colônias granulosas de cor branco-amareladas confirmando o diagnóstico de Nocardia brasiliensis. 0 paciente foi tratado com a associação sulfametoxazol-trimetoprima ( 800/ $160 \mathrm{mg}$ ) duas vezes ao dia, durante 12 meses. Houve melhora completa do quadro infeccioso e da sintomatologia correspondente, permanecendo apenas hipercromia residual na região afetada.

\section{REFERENCES}

1. Castro LG, Belda Junior W, Salebian A, Cuce LC. Mycetoma: a retrospective study of 41 cases in São Paulo, Brazil, from 1978 to 1989. Mycoses 36: 89-95, 1993.

2. Kiska DL, Hicks K, Pettit DJ. Identification of medically relevant Nocardia species with an abbreviated battery of tests. Journal of Clinical Microbiology 40:1346-1351, 2002.

3. Zgraggen WJ, Bregenzer H, Fankhauser H, Arnoux A, Laeng H, Itin PH. Primary cutaneous nocardiosis in an immune-competent patient. European Journal of Dermatology 11: 569-571, 2001. 